\title{
Esp Students' Needs Analysis Based On The Learning-Centred Approached
}

\author{
Fransiska Way Warti \\ Polytechnic of Tonggak Equator Pontianak \\ e-mail: Siska_mw@yahoo.com

\begin{tabular}{ccc}
\hline Diterima & Direvisi & Disetujui \\
$05-08-2020$ & $23-08-2020$ & $26-08-2020$ \\
\hline
\end{tabular}

\begin{abstract}
English for Specific Purposes, known as ESP, has been a requirement in the field of English Language Teaching especially in the vocational college level.This case study aims at investigating the ESP language needs of students at Politeknik Tonggak Equator in Pontianak. The need analysis was based on the Hutchinson \& Waters model, The Learning-Centered Approach Model, which is classified into two: target situation needs and learning needs. This study focused on the target need that includes "necessities", "lacks" and "wants" aspects. Interviews to infer information for qualitative analysis were conducted with 10 students at the sixth semester of English Business and Management program. The findings revealed that students who were working at various companies confirmed that their necessities were to learn a much better English skilled to support their works. In terms of lacks, some learners admitted that they had to improve their communication skills and the wants were to be able to communicate in the form of speaking and writing.
\end{abstract}

Keywords: ESP, need analysis, the learning centered approach

\begin{abstract}
Abstrak - English for Specific Purposes (ESP) sudah menjadi sebuah tuntutan dalam bidang pengajaran bahasa Inggris, terutama pada pendidikan vokasi. Studi kasus ini bertujuan untuk meneliti kebutuhan ESP pada mahasiswa Politeknik Tonggak Equator. Analisis kebutuhan ini berdasarkan pada model Hutchinson \& Waters, The Learning-Centered Approach Model, yaitu Target Situation Needs dan Learning Needs. Penelitian ini berfokus pada Target Needs yang terbagi atas Necessities, Lacks, Wants. Wawancara untuk mendapatkan data kualitatif dilakukan pada 10 mahasiswa semester enam jurusan Business English and Management. Hasil penelitian mengungkapkan bahwa mahasiswa yang bekerja pada berbagai industri tersebut mempunyai kebutuhan untuk belajar bahasa Inggris profesi demi menunjang pekerjaan mereka. Dalam kesenjangan kemampuan, mahasiswa mengakui mereka perlu memperbaiki ketrampilan berkomunikasi dan keinginan mereka adalah agar mampu berkomunikasi dalam bentuk speaking dan writing.
\end{abstract}

Kata kunci : ESP, analisis kebutuhan, the learning centred approach

\section{INTRODUCTION}

English as the international language of business trade has expanded and brought countries into contact. English also performs an essential role in education across the world. The unfold of business, scientific and technical activities at international scale along with the needs of international communication in various fields has expanded the demand of English especially in countries where English is taught as Foreign Language (Hutchinson \& Waters, 1987). Hutchinson and Waters additionally stated, "As English became the widely wide-spread worldwide language of technology and commerce, it created a new technology of newcomers who knew especially why they were mastering a language".

At the vocational university level, English language curriculum has included ESP (English for
Specific Purposes) as ESP is not only needed as a language most graduates will need in competing for jobs but also demanded in daily communication at work. Therefore, the scholars as job seekers are demanded to equip themselves with extensive English. Not only that, English proficiency is additionally a requirement as one of the keys to success in a career nowadays. Because of the consequence of the demands, the education providers have the requirement to supply the ESP course in their curriculum. Medrea and Rus (Medrea \& Rus, 2012) has a similar point of view pronouncing that " Students' needs in nowadays global economy are focused not only on the competencies to read, write, listen and speak English fluently but also on the power to speak in an exceedingly way which is able to be known and appreciated by their counterparts within. the worldwide working setting “. The English instructors usually have to design teaching syllabus 
and learning materials for the ESP program using methodologies and techniques that is suitable for the students' needs. Similarly, at Politeknik Tonggak Equator, the lecturers were struggling to style teaching materials due to the lack of ESP-associated books in particular for vocational students. In order to be able to layout a correct syllabus, the analysis of students ' needs is going to be a vital step in supplying college students with a well-designed teaching material.

The ESP method to pedagogy will be a response to practical matters, like the necessity to arrange teaching materials to students who have mastered the general English. However, the need to use English for a more unique working situation, at some stage in this case, the business students have to analyze English and to be equipped to communicate correctly of their works. Needs evaluation nowadays is employed to discover the precise English language needed in a range of professions, over a good range of disciplines and in many international settings. As one of the English language lecturers in Politeknik Tonggak Equator Pontianak who will teach and design ESP program, the author intend to do the needs analysis for ESP students at Semester 6 academic year 2018-2019.

The theoretical foundation used for the need analysis is a vital concept to see where the researchers stand and the way she views the phenomena that occur. The theories that were stated and covered were relevant theories for discussing the study

\section{English for Specific Purposes (ESP)}

The most quoted definitions of ESP were as follows:

1. Hutchinson and Waters (Hutchinson \& Waters, 1987) define ESP an approachmeaning that it involves no explicit form of language- teaching material or methodology. The most important element of learning English is the 'purpose' why the learner is learning the language. The authors stated" ESP is an approach to language instruction during which all selections on content and methodology are supported the learner's reasons for learning.' (Hayban et al., 2015)

2. Mackay and Mountford (Mackay, R., \& Mountford, 1978) argue that ESP refers to the teaching of English for a utilitarian purpose (the purpose refers to the requirements of learners in tutorial, scientific or professional studies), build an evidence of the notions as; the notion of 'special language' with a limited list of words and expressions picked from the whole language since that restricted list covers every requirement within a context, task or profession. However, the term 'specialized aim' is employed to confer with the rationale that a learner learns a language. As a result, the word 'special' in ESP refers to the 'purpose', not the actual jargon learners learn.

3. Paltridge and Starfield (Paltridge, B., \& Starfield, 2013) expressed that English for specific purposes (ESP) refers to the teaching and learning of English as a second or foreign language wherever the goal of the learners is to use English in a definite domain.

4. Tony Dudley-Evans (Dudley-Evans \& St John, 1998) define ESP in terms of absolute and variable characteristics that include:

a. ESP is meant to satisfy the particular needs of the learners in various disciplines that produce use of the underlying methodology and activities of the disciplines it serves;

b. ESP being targeted on the language, skills, discourse and genres that are thought to be relevant to the above-mentioned activities. For example, ESP which is meant for mature learners in a higher education or a very skilled work scenario.

c. ESP is intended for intermediate or advanced language level students, the fundamental knowledge of scheme being important but not compulsory, therefore it is possible to be designed for beginner learners as well.

In general, the experts agree on the actual fact that ESP is a process of developing a course considering the language level and therefore the needs of the learners to satisfy their particular professional and academic necessities.

\section{Need Analysis}

Needs analysis could be a procedure for locating and outlining relevant syllabus, educational and administration objectives so as to form a suitable learning environment. The learning atmosphere is associated to the real-life conditions of the scholars. Needs analysis has been thought to be a requirement in any course design.

Hutchinson and Waters (Hutchinson \& Waters, 1987) outlined needs as necessities, wants and lacks, while Brindley (Brindley, 2012) explained it as "the gap between what the learners' actual needs are and what should be tutored to 
them." Therefore, it is said that needs are what learners are required to try and do with a foreign language in a target situation, and how learners might best master the target language during the period of coaching. Brindley also suggests that objective and perceived needs are the requirements that are obtained by outsiders from the facts, from what is known and might be verified. As an example, if students learn English to meet their requirements for graduation, then their needs to study English are objective and perceived. In contrast, if the wants are obtained by insiders and correspond to cognitive and affective aspects like 'to be confident' or 'to help a person be more capable in one's school or workplace' then the wants are subjective or felt needs (Brindley, 2012) .

From above theories, it can be concluded that needs analysis is defined as a specific ground for a future development of the educational activities of a particular group of leaners.

\section{Hutchinson and Waters' Model of Needs Analysis}

Hutchinson and Waters (Hutchinson \& Waters, 1987) first implied the Learning-Centered Approach needs analysis model which is catagorized into of two parts. They are target situation needs and learning needs. Target needs include "necessities", "lacks" and "wants".

1. Necessities are determined by the demand of the target situation. They are the required needs that enable the learner to use effectively within the target situation. For instance, a business person should learn the language to enable him to grant a business speech a presentation or write a sales report

2. Lacks are the gap between "necessities" and what the learner already knows, which is the current proficiency of the learners. By investigating what the learners know, ESP instructors can decide which necessities the learners lack.

3. Wants are learners' subjective needs or what the learners want to be told. A learner's wants may not necessarily be the learner's real need to function effectively within the target situation.

Learning needs, on the opposite hand, are how learners learn the language. Learning needs are about the learners' motivation of learning the language, the way they like to be told, the available resources, the time and place the course will occur and therefore the learners' personal information.

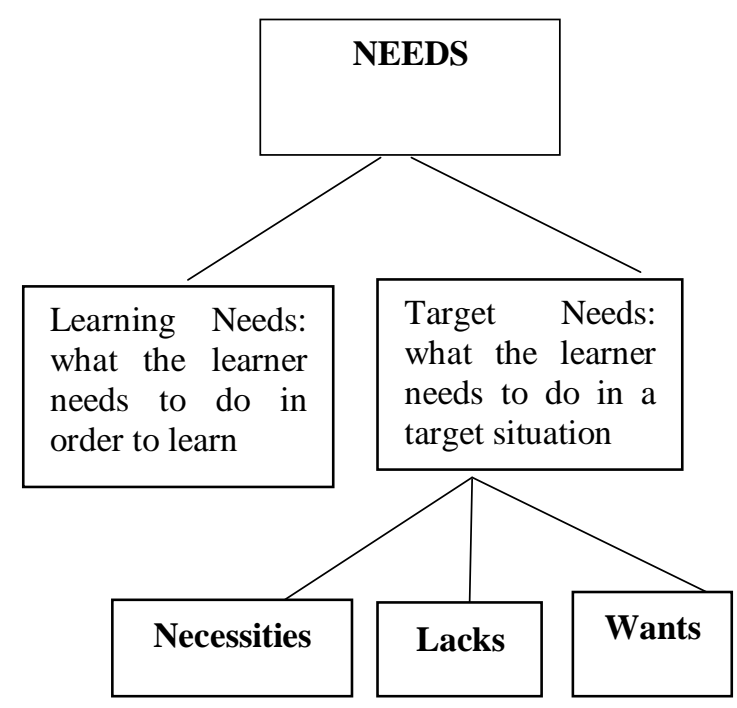

Figure 1 - Hutchinson and Waters' Model

However, the scope of this study is merely on the target needs of the learners at Politeknik Tonggak Equator. The result is anticipated to contribute to the ESP instructors who would like to develop the knowledge within the area of ESP teaching. Thus, the results of this study are often used as a reference to conduct a relevant study. Additionally, this study will enable them to be aware of the needs analysis in designing a proper syllabus that meets the students' needs within the ESP language and therefore the language skills. Finally, for the scholars, this study hopefully is the answers to help them in improving their language competencies.

\section{RESEARCH METHODOLOGY}

\section{Research Design}

This research employed a qualitative research method. According to Creswell (Creswell, 2014), qualitative research is an umbrella term used to refer to the theoretical perspectives designs as: narrative, phenomenology, grounded theory, action research, case study, ethnography, historical research, and content analysis.

The approach of the research was a case study which Creswell defines as involves a deep understanding through several types of data sources, especially evaluation in which the researcher can develop an analysis of a case, program, event, activity, and process

\section{Place and Time of Research}


The research was conducted in Politeknik Tonggak Equator Pontianak located in Jalan Fatima 1-2, Pontianak, Kalimantan Barat and the time frame was from June - December 2018

\section{Participants of the Research}

The data was obtained from the students at semester 6th of The English Business and Management Program academic year 2018-2019 at Politeknik Tonggak Equator Pontianak. Purposive sampling was used to pick out 10 students who except students at Politeknik Tonggak Equator were also professionals that worked in different jobs. Purposive sampling is a non-consultant subset of some large population and is constructed to serve a completely specific need and purpose. This involves figuring out and choosing people or groups of people which can be specifically knowledgeable approximately or experienced with a phenomenon of interest (Creswell, 2014). The author supposed to gather records from members or informants who labored in distinctive jobs in order to investigate their necessities, lacks, wants in relation to the ESP program at the Politeknik.

\section{Data Collection Technique and Instrument}

According to Creswell (Creswell, 2014) a case study is conducted by using multiple sources like questionnaires, interviews, observations, written accounts, and audio-visual materials. In this research, the main instrument will be an interview that consists of semi-structured questions. The interview was composed based on the need analysis model of Hutchinson and Waters which will focus on the target needs of the students at Politeknik Tonggak Equator which is on necessities, lacks, wants aspects. The interview was conducted in a small group and individually with the objective to answer the research questions on what is the ESP language needs of students at Business English and Management program at Politeknik Tonggak Equator in Pontianak.

\section{Data Analysis}

The data obtained in this research was analysed qualitatively. Qualitative data analysis is complicated by the volume of data generated, and the challenge for the researcher is to conduct an indepth analysis, and yet presents the findings in a concise and logical way (Creswell, 2014).

Meanwhile, Creswell additionally stated that case study studies is a qualitative technique wherein the investigator explores a bounded system (a case) or more than one bounded systems (cases) through the years through detailed, in-depth information collection involving more than one assets of information (e.g., observations, interviews, audiovisual material, and documents and reports) and reviews a case description and case-based themes

The data obtained was analyzed by giving a code and catagorised in suitable themes. Next, the data were grouped based on the similarity of the theme and analyzed manually to identify the final results. Finally, researcher read, described, compared, and blended the codes to conclude the findings.

\section{FINDINGS AND DISCUSSION}

In this chapter, the findings and discussions of results gained from the data collection instruments are presented. There is also a presentation of the background of the informants to show that they are working in different industries. The ESP language needs analysis is focused on finding out the learners' target needs which include necessities, lacks, and wants.

Table 1 Profile of the participants

\begin{tabular}{|lll|}
\hline 1 & Participant & Admin in Kapuas Dharma Hotel \\
& 1 & \\
\hline 2 & Participant & Secretary in a car showroom \\
& 2 & \\
\hline 3 & Participant & Sales in a food company \\
& 3 & \\
\hline 4 & Participant & Bookkeeper in a furniture shop \\
& 4 & \\
\hline 5 & $\begin{array}{l}\text { Participant } \\
5\end{array}$ & Sales and marketing staff in a car dealer \\
& & \\
\hline 6 & Participant & Sales in a property agent \\
& 6 & \\
\hline 7 & Participant & Beauty salon owner \\
& 7 & \\
\hline 8 & Participant & Room teacher in a bilingual \\
& 8 & kindergarten \\
\hline 9 & $\begin{array}{l}\text { Participant } \\
9\end{array}$ & Private English tutor for Primary school \\
\hline 10 & $\begin{array}{l}\text { Participant } \\
10\end{array}$ & Receptionist in a hotel \\
\hline & & \\
\hline S0ure: Prossed & \\
\hline
\end{tabular}

Source: Processed Data (2019) 
Table 1 describes the informants' workplace and their job types. It showed different industries and different positions. It can also be concluded that the dominants positions are sales, also educational positions followed by administration work such as administration staff, secretary, receptionist.

The research finding is to answer the research questions that formulated before. What is the ESP language needs of Business English and Professional Communication program's students at Politeknik Tonggak Equator in Pontianak?

The result will be described based on the target needs which cover the necessities, lacks and wants aspects.

\section{Necessities}

Necessities are about what the English needed in order to communicate in their workplace or the target situation for their job at the time. In order to answer that, the writer asked:

\section{Why English is necessary in your job?}

2. How do you use English in your work?

Here are some results revealed from participants:

P1: I Need to be able to communicate with guests from overseas, explain about directions, the local place of interests, etc.

P2: My job requires me to write business letters in English and speak to my boss' guests who are from Malaysia, Singapore, UK, USA.

P3: I need to know English so I can read the food label and understand that they are so I can explain to my customers

P4: My company exports furniture to Arabic countries, therefore I need to know English in order to understand the items sent to the clients

P5: Car specifications are written in English so I need to understand them

P6: Our buyers sometimes are from Malaysia and Singapore and I have to explain to them about the property they are interested in buying.

P7: I like to know English to be able to understand the new trends in my business.

P8: English is a must in my profession as a Bilingual teacher. I speak English to my students in the classroom
P9: I need to know English better in order to help my students in English tutoring

P10: We have guests from many foreign countries during the big event such as Cap Go Meh or Kulminasi Matahari at Tugu Katulistiwa. I want to be able to speak to them about the history of the events.

\section{Lacks}

The interviews were to find out what the students have known and what they should know. The gap between those situations will be described as follows. The writers asked the participants to self-evaluated their level of English then asked them what they think they should know. The questions are formulated below:

1. What do you think of your level of English?

2. What do you think you need to learn to be able to perform well in your job?

P1: I think my English is at the intermediate level. I can read and listen to English Ok but I realize that I need a wider range of vocabularies and especially when I have to write in English

P2: Maybe I am in an intermediate level as I supposed to be. I do not have problem speaking and reading in English but I still have to learn a lot to write in formal professional English

P3: I don't know my level but I can understand basic conversation. But I find it difficult to understand the food language in the market. So I do need to study more vocabularies of the products I sell.

P4. I don't have to speak to foreign clients but I want to know more about the language in the shipping document that we have with them. And some terms about furniture process and materials

P5 I maybe in the intermediate level since I learned English in every semester in Polteq and I am now semester 5 going to semester 6. My problem in English is understanding the manual from the car manufacturer. I wish I can learn more vocabularies in ESP course. And the technical language.

P6: I write to my overseas clients in English and sometimes speak to them when they come to visit. To me, it's easy to write than to speak. When writing I can check my mistake but not when I speak. Oh, I maybe in Intermediate level like my other friends 
P7: My English level. It's hard to evaluate yourself but I think I am in an OK level. But I will want to understand more when I read news on the internet about new trends in hair and salon industry.

P8: I am definitely upper intermediate from the last TOEFL score. But of course I will need to be better in my grammar and communication in English as I will be teaching in English language.

P9: I am probably Intermediate and I definitely want to increase my English to the next level so I can use English properly when I teach.

P10: I think I am in an intermediate level as I have to as a requirement for my job but I would like to learn more language of hotel industry so I could speak and write better in my job.

\section{Wants}

In order to find out the subjective needs or what the learners want to learn, the writer asked questions:

1. What would you like to achieve in the course?

2. What specific skills would you like to improve?

P1: I would like to learn to communicate with people using English. I think I want to have more vocabularies and a better speaking confidence

P2: I like to achieve a better writing skill so I can write the business letter .an international standard letter.

P3: I want to speak with a good English. I want to be a good communicator

P4: The thing I want from this course is the knowledge about export-import language. I think I need to improve my reading and writing skill.

P5: The course should give me a skill to understand the English in the automobile business. I think it is important to understand more vocabularies in my situation.

P6: I like to communicate without overseas buyers. I will need more vocabularies and good speaking skill.

P7: I do not need to speak to a client so I do not need communication skill but I want to learn English to understand the hairstyle magazines from foreign countries

P8: I would like to learn how to teach English better but I don't think I can get it in ESP course.
However, I would get advantage from the fours skills in English if I enroll in the course. Hopefully.

P9: As a tutor I would like to speak and write better English. More vocabularies will be helpful for my job. And communication skill as well.

P10: A conversation practice might help me to improve my confidence in talking to our hotel customers. I also need to learn more related vocabularies.

\section{DISCUSSION}

The need analysis was conducted to find out the learners' target needs based on Hutchinson and Waters needs analysis. The focus was on the necessities, lacks, wants of the students at Semester 6 of Politeknik Tonggak Equator.

The interviews were used to find out why the students needed to enroll in ESP class. What they thought they needed to learn and to what extend they thought they needed English in their jobs, study, social life. The details are as follows:

\section{Necessities:}

In this aspect, most of them confirmed that they needed to enroll in ESP to learn a better professional English to support them in their works. For example, those who worked as an admin, secretary or bookkeeper thought that they needed specific English related to their works such as writing business letter, reading English label, understanding vocabularies of certain products, so they could function properly. The similar perspective of the participants who worked as salesmen in which they suggested that they could do with some conversational English to communicate with their clients. Meanwhile, the participants who worked as teachers and tutors stated that ESP was important for perfecting the communication skills in teaching.

\section{Lacks:}

The interviews intended to find out what is the gap between the participants' current competence and the English that they needed in their works. Most of them answered that Intermediate levels were sufficient English as they could understand a variety of texts and follow a variety of conversation well, but they expected to learn more through the ESP course. Those announcing that they needed to improve conversation skills were working in a workplace that required the staff to use speak English in interacting with other people such as teacher, tutor, hotel receptionist. On the other hand, salespersons 
in this study thought they would be benefited by learning more vocabularies of the products that they were selling.

\section{Wants:}

Wants are considered the subjective needs of learners that require the students to know what they want to be learned. From that situation, students will do some efforts to achieve their goals. The writer had categorized the wants based on four language skills which are reading, writing, speaking and listening. Most desired abilities the participants mentioned were communication in the form of speaking and writing, supported with sufficient vocabularies closely related to their industries. Since there was a wide range of industries they involved in, the vocabularies range they required were also different depending on the demand of their jobs.

\section{CONCLUSION}

The findings have provided useful information about students' needs in ESP course at Politeknik Tonggak Equator which could be utilized to develop an ESP program, which was incorporated into the ESP syllabus.

Based on the interviews and analysis it can be concluded that ESP is a goal-oriented and focused learning in fulfilling the learners' academic and professional needs. Since most of the participants at Politeknik Tonggak Equator were professionals, their needs were highlighted to achieve specific English knowledge that they could use in their workplaces.

The recommendations would be for the lecturers in the ESP to gain a solid knowledge of some fundamental aspects of ESP and ESP theoretical models of needs assessment to enable them to design a program that will meet the needs of their learners. In other words, ESP instructors should design courses according to their students' professional needs, having in mind their target language use situation.

\section{REFERENCES}

Brindley, G. (2012). The role of needs analysis in adult ESL programme design. In The Second Language Curriculum. https://doi.org/10.1017/cbo9781139524520.00 7

Creswell, J. (2014). Qualitative Inquiry \& Research
Design: Choosing among Five Approaches (4th ed.). Thousand Oaks, CA: SAGE. SAGE.

Dudley-Evans, T., \& St John, M. J. (1998). Developments in English for Specific Purposes. A Multi-Disciplinary Approach. Ibérica. $\quad$ https://doi.org/10.1016/S08894906(99)00026-5

Hayban, O., Hajana, O., Mohammed, A., \& Adam, A. (2015). the Role of Needs Analysis for the Quality of English for Specific Purposes and English for Academic Purposes Course Design. International Journal of Recent Scientific Research, 6(5), 3868-3871.

Hutchinson, T., \& Waters, A. (1987). English for Specific Purposes. In English for Specific Purposes. Cambridge University Press. https://doi.org/10.1017/cbo9780511733031

Mackay, R., \& Mountford, A. (1978). Mackay, R., \& Mountford, A. (1978). The teaching of English for Specific Purposes: theory and practice. London: Longman

Medrea, N., \& Rus, D. (2012). Challenges in Teaching ESP: Teaching Resources and Students' Needs. Procedia Economics and Finance, 3(12), 1165-1169. https://doi.org/10.1016/s22125671(12)00291-2

Paltridge, B., \& Starfield, S. (2013). Paltridge, B., \& Starfield, S. (2013). The Handbook of English for Specific Purposes. West Sussex. West Sussex. 